dr inż. Marek Sobaś

Instytut Pojazdów Szynowych ,TABOR”

\title{
Środki konstrukcyjne i technologiczne zwiększające wytrzymałość zmęczeniową sprężyn śrubowych
}

\begin{abstract}
$W$ artykule przedstawiono zagadnienia zwiększenia wytrzymałości zmęczeniowej sprężyn śrubowych usprężynowania pierwszego stopnia wózków wagonów towarowych Y25L. Zwiększenie wytrzymatości zmęczeniowej można osiagnać dobierajac odpowiednio materiat pręta oraz stosujac zabiegi technologiczne. Omówiono czynniki, które przyczyniaja się do zwiększenia żywotności sprężyn, jak $n p$. prawidtowe użycie tlumika ciernego czy też zabezpieczenie antykorozyjne.
\end{abstract}

\section{WSTĘP}

Obliczenia wytrzymałościowe sprężyn wózków wagonów towarowych typu Y25L wykazały, że są one mocno wytężone $[3,4]$. W związku z powyższym, aby zachować wymaganą żywotność sprężyn konieczne jest:

- właściwy dobór materiałów na pręty, z których zwijane są sprężyny śrubowe, których przydatność jest potwierdzona przez testy statyczne i zmęczeniowe $\mathrm{w}$ akredytowanych laboratoriach badawczych; materiały te powinny odpowiadać normie europejskiej EN 10089:2002 [12];

- przestrzeganie procesu technologicznego, który jest opisany w karcie UIC 822 [10] oraz w normie europejskiej PN-EN 13298:2003 [13];

- właściwe zabezpieczenie antykorozyjne sprężyn śrubowych;

- przestrzeganie zasad właściwej eksploatacji, polegającej na utrzymaniu thumika ciernego $\mathrm{W}$ ciagłej gotowości do thumienia drgań.

Sprężyny nośne zawieszenia wózków wagonów towarowych są istotnymi elementami, pełniącymi ważną rolę $\mathrm{w}$ zapewnieniu bezpieczeństwa przed wykolejeniem oraz zapewniaja wymagane własności dynamiczne zgodnie z PN-EN 14363:2007 [14].

Wynika $z$ tego, że przed producentami sprężyn wózków wagonów towarowych postawiono poważne wyzwanie. W przypadku występowania bardzo dużego wytężenia materiału i wyczerpaniu wszystkich środków konstrukcyjnych, szczególną rolę pełni technologia wytwarzania sprężyn. Dobór odpowiednich środków technologicznych musi zapewnić wymaganą wytrzymałość statyczną oraz zmęczeniową, a tym samym żywotność sprężyn. Wymagane środki technologiczne powinny wynikać z dokumentacji konstrukcyjnej. W przypadku stwierdzenia pęknięcia sprężyny (sprężyn) wagon zostaje wyłączony z ruchu, co obciąża kosztowo przede wszystkim użytkownika wagonu. Biorąc pod uwagę, że wagony towarowe są w większości przystosowane do ruchu międzynarodowego, sprawność techniczna wagonu oraz zapewnienie żywotności poszczególnych części na właściwym poziomie jest sprawą priorytetową. Wagony towarowe na wózkach Y25L spełniają wymagania przejazdu przez tory wichrowate zgodnie $\mathrm{z}$ raportem ORE/ERRI B55 oraz wymagania zamienności wymienione $\mathrm{W}$ karcie UIC 510-1 [7], raporcie ORE/ERRI B12/Rp17 [16], raporcie ORE/ERRI B12 [15] i w przepisach TSI [18]. Wózki Y25L spełniają wymagania dynamiczne, wymienione w karcie UIC 432 [5], karcie UIC 518 [9] oraz PN-EN 14363:2007 [14]. Sprężyny wózka Y25L są wymienione jako elementy standardowe w karcie UIC 517 [8], natomiast wózki jako zespoły standardowe w karcie UIC 500 [6].

\section{Dobór materiału na sprężyny}

$\mathrm{Na}$ sprężyny zawieszenia wózków rodziny Y25L należy stosować stale zgodne z EN 10089:2002 [12]. Prawidłowy dobór materiału jest kluczową sprawa, pomimo standardowego charakteru sprężyn. Biorąc pod uwagę, że naprężenia dopuszczalne przy zblokowaniu $\tau_{\mathrm{ZULBLOCK}}=0,56 \cdot \mathrm{R}_{\mathrm{m}}$, dobór stali na sprężyny zawieszenia powinien odbywać się zgodnie z tabelą 1 . 
Orientacyjne wartości wlasności mechanicznych ulepszonych cieplnie próbek stali (przeznaczonych do sprężyn zawieszenia) do badań

Tabela 1

\begin{tabular}{|c|c|c|c|c|c|c|c|c|c|}
\hline \multicolumn{2}{|c|}{ Oznakowanie } & \multirow{2}{*}{$\begin{array}{c}\begin{array}{c}\text { Temp. } \\
\text { hartowania } \\
\pm \mathbf{1 0}^{\circ} \mathbf{C}\end{array} \\
880\end{array}$} & \multirow{2}{*}{$\begin{array}{c}\begin{array}{c}\text { Ośrodek } \\
\text { hartowniczy }\end{array} \\
\text { woda }\end{array}$} & \multirow{2}{*}{$\begin{array}{c}\text { Temp. } \\
\text { odpuszczania } \\
\pm \mathbf{1 0}^{\circ} \mathbf{C}\end{array}$} & \multirow{2}{*}{$\frac{\begin{array}{c}\mathbf{R}_{\mathbf{p} 0,2} \\
{[\mathbf{M P a}]}\end{array}}{1150}$} & \multirow{2}{*}{$\begin{array}{c}\begin{array}{c}\mathbf{R}_{\mathbf{m}} \\
{[\mathbf{M p a ]}}\end{array} \\
1300 \div \\
1600\end{array}$} & \multirow{2}{*}{$\left.\begin{array}{c}\text { A } \\
{[\%]}\end{array}\right]$} & \multirow{2}{*}{$\left.\begin{array}{c}\mathbf{Z} \\
{[\mathbf{\%}]}\end{array}\right]$} & \multirow{2}{*}{$\begin{array}{c}\begin{array}{c}\mathbf{K U} \\
\mathbf{w} \\
\mathbf{2 0} \mathbf{}^{\circ} \mathbf{C}\end{array} \\
18\end{array}$} \\
\hline $38 \mathrm{Si} 7$ & 1.5023 & & & & & & & & \\
\hline $46 \mathrm{Si} 7$ & 1.5024 & 880 & woda & 450 & 1250 & $\begin{array}{c}1400 \div \\
1700\end{array}$ & 7 & 30 & 15 \\
\hline $56 \mathrm{Si} 7$ & 1.5026 & 860 & olej & 450 & 1300 & $\begin{array}{c}1450 \div \\
1750\end{array}$ & 6 & 25 & 13 \\
\hline $55 \mathrm{Cr} 3$ & 1.7176 & 840 & olej & 400 & 1250 & $\begin{array}{c}1400 \div \\
1700\end{array}$ & 3 & 20 & 5 \\
\hline $60 \mathrm{Cr} 3$ & 1.7177 & 840 & olej & 400 & 1300 & $\begin{array}{c}1450 \div \\
1750\end{array}$ & 3 & 20 & 5 \\
\hline 54SiCr6 & 1.7102 & 860 & olej & 450 & 1300 & $\begin{array}{c}1450 \div \\
1750\end{array}$ & 6 & 25 & 8 \\
\hline $56 \mathrm{SiCr} 7$ & 1,7106 & 860 & olej & 450 & 1350 & $\begin{array}{c}1500 \div \\
1800\end{array}$ & 6 & 25 & 8 \\
\hline $61 \mathrm{SiCr} 7$ & 1.7108 & 860 & olej & 450 & 1400 & $\begin{array}{c}1550 \div \\
1850\end{array}$ & 5,5 & 20 & 8 \\
\hline $51 \mathrm{CrV} 4$ & 1.8159 & 850 & olej & 450 & 1200 & $\begin{array}{c}1350 \div \\
1650\end{array}$ & 6 & 30 & 8 \\
\hline 45SiCrV6-2 & 1.8151 & 880 & olej & 400 & 1550 & $\begin{array}{c}1600 \div \\
1900\end{array}$ & 7 & 40 & 13 \\
\hline 54SiCrV6 & 1.8152 & 860 & olej & 400 & 1600 & $\begin{array}{c}1650 \div \\
1950\end{array}$ & 5 & 35 & 8 \\
\hline $60 \mathrm{SiCrV} 7$ & 1.8153 & 860 & olej & 400 & 1650 & $\begin{array}{c}1700 \div \\
2000\end{array}$ & 5 & 30 & 5 \\
\hline 46SiCrMo6 & 1.8062 & 880 & olej & 450 & 1400 & $\begin{array}{c}1550 \div \\
1850\end{array}$ & 6 & 35 & 10 \\
\hline 50SiCrMo6 & 1.8063 & 890 & olej & 450 & 1420 & $\begin{array}{c}1650 \div \\
1950\end{array}$ & 6 & 30 & 5 \\
\hline 52SiCrNi5 & 1.7117 & 860 & olej & 450 & 1300 & $\begin{array}{c}1450 \div \\
1750\end{array}$ & 6 & 35 & 10 \\
\hline $52 \mathrm{CrMoV} 4$ & 1.7701 & 860 & olej & 450 & 1300 & $\begin{array}{c}1450 \div \\
1750\end{array}$ & 6 & 35 & 10 \\
\hline 60CrMo3-1 & 1.7239 & 860 & olej & 450 & 1300 & $\begin{array}{c}1450 \div \\
1750\end{array}$ & 6 & 30 & 8 \\
\hline 60CrMo3-2 & 1.7240 & 860 & olej & 450 & 1300 & $\begin{array}{c}1450 \div \\
1750\end{array}$ & 6 & 30 & 8 \\
\hline 60CrMo3-3 & 1.7241 & 860 & olej & 450 & 1300 & $\begin{array}{c}1450 \div \\
1750\end{array}$ & 6 & 30 & 8 \\
\hline
\end{tabular}

Jak widać $\mathrm{z}$ przedstawionej tabeli 1 dopuszczalne $\tau_{\text {ZULBLock }}$ (bez uwzględnienia współczynnika Wahla), w zależności od gatunku stali zawiera się $\mathrm{w}$ przedziale $728 \mathrm{MPa} \div 1120 \mathrm{MPa}$.

Skład chemiczny stali stopowych, wymienionych w tabeli 1 i zalecanych do użycia na sprężyny śrubowe, pracujące przy wysokich obciążeniach jest podany $w$ tabeli 2 .

\section{Technologia wykonania sprężyn śrubowych}

3.1. Zasadnicze operacje technologiczne przy wytwarzaniu sprężyn śrubowych

Zgodnie z kartą UIC 822 [10] sprężyny zawieszenia wózków wagonów towarowych typu Y25L wykonuje się stosując proces technologiczny, podzielony na następujące operacje:
- podgrzewanie pręta, przeznaczonego na sprężyny $\mathrm{w}$ piecu $\mathrm{z}$ kontrolowaną atmosfera, aby uniknąć procesu odwęglenia, temperatura podgrzewania wynosi ok. $900{ }^{\circ} \mathrm{C}$, po osiagnięciu ww. temperatury odbywa się formowanie końców sprężyny przez dwa walce ułożone wzdłużnie oraz dwa walce pionowe, które są odpowiedzialne za szerokość końców pręta, które odpowiada średnicy pręta; walce są sterowane przez centrum komputerowe;

- następnie pręt jest poddany wygrzewaniu w temperaturze austenityzacji (ok. $930^{\circ} \mathrm{C}$ )

- zwijanie pręta na gorąco na trzpieniu zwijarki, który nadaje średnicę wewnętrzną sprężyny, skok zwojów jest sterowany za pomocą komputera; 
Gatunki wymagany skład chemiczny (dotyczący analizy wytopowej) stali, przeznaczonych do sprężyn zawieszenia

Tabela 2

\begin{tabular}{|c|c|c|c|c|c|c|c|c|c|c|c|c|}
\hline & Oznaczenie & \multicolumn{11}{|c|}{ Zawartość procentowa pierwiastków [\%] } \\
\hline L.p & Znak stali & Numer & $\mathbf{C}$ & Si & Mn & $\mathbf{P}_{\text {MAX }}$ & $\mathbf{S}_{\text {MAX }}$ & $\mathbf{C r}$ & $\mathbf{N i}$ & Mo & $\mathbf{V}$ & $\begin{array}{c}\mathrm{Cu}+ \\
\mathbf{S n}\end{array}$ \\
\hline 1. & $38 \mathrm{Si7}$ & 1.5023 & $0,35 \div 0,42$ & $1,50 \div 1,80$ & $0,50 \div 0,80$ & 0,025 & 0,025 & & & & & \\
\hline 2. & $46 \mathrm{Si7}$ & 1.5024 & $0,42 \div 0,50$ & $1,50 \div 2,0$ & $0,50 \div 0,80$ & 0,025 & 0,025 & & & & & \\
\hline 3. & $56 \mathrm{Si7}$ & 1.5026 & $0,52 \div 0,60$ & $1,60 \div 2,0$ & $0,60 \div 2,00$ & 0,025 & 0,025 & & & & & \\
\hline 4. & $55 \mathrm{Cr} 3$ & 1.7176 & $0,52 \div 0,59$ & $\max 0,40$ & $0,70 \div 1,00$ & 0,025 & 0,025 & $0,70 \div 1,00$ & & & & \\
\hline 5. & $60 \mathrm{Cr} 3$ & 1.7177 & $0,55 \div 0,65$ & $\max 0,40$ & $0,70 \div 1,00$ & 0,025 & 0,025 & $0,60 \div 0,90$ & & & & \\
\hline 6. & 54SiCr6 & 1.7102 & $0,51 \div 0,59$ & $1,20 \div 1,60$ & $0,50 \div 0,80$ & 0,025 & 0,025 & $0,50 \div 0,80$ & & & & \\
\hline 7. & $56 \mathrm{SiCr} 7$ & 1.7106 & $0,52 \div 0,60$ & $1,60 \div 2,0$ & $0,70-1,00$ & 0,025 & 0,025 & $0,20 \div 0,45$ & & & & \\
\hline 8. & 61SiCr7 & 1.7108 & $0,57 \div 0,65$ & $1,60 \div 2,0$ & $0,70-1,00$ & 0,025 & 0,025 & $0,20 \div 0,45$ & & & & \\
\hline 9. & $51 \mathrm{CrV} 4$ & 1.8159 & $0,47 \div 0,55$ & $\max 0,40$ & $0,70-1,10$ & 0,025 & 0,025 & $0,90 \div 1,20$ & & & $\begin{array}{l}0,10 \div \\
0,25\end{array}$ & \\
\hline 10. & 46SiCrV6-2 & 1.8151 & $0,40 \div 0,50$ & $1,30 \div 1,70$ & $0,60 \div 0,90$ & 0,025 & 0,025 & $0,40 \div 0,80$ & & & $\begin{array}{l}0,10 \div \\
0,20\end{array}$ & \\
\hline 11. & 54SiCrV6 & 1.8152 & $0,51 \div 0,59$ & $1,20 \div 1,60$ & $0,50 \div 0,80$ & 0,025 & 0,025 & $0,50 \div 0,80$ & & & $\begin{array}{l}0,10 \div \\
0,20\end{array}$ & \\
\hline 12. & $60 \mathrm{SiCrV7}$ & 1.8153 & $0,56 \div 0,64$ & $1,50 \div 2,00$ & $0,70 \div 1,00$ & 0,025 & 0,025 & $0,20 \div 0,40$ & & & & \\
\hline 13. & 46SiCrMo6 & 1.8062 & $0,42 \div 0,50$ & $1,30 \div 1,70$ & $0,50 \div 0,80$ & 0,025 & 0,025 & $0,50 \div 0,80$ & & $\begin{array}{l}0,20 \div \\
0,30\end{array}$ & & \\
\hline 14. & 50SiCrMo6 & 1.8063 & $0,46 \div 0,54$ & $1,40 \div 1,80$ & $0,70 \div 1,00$ & 0,025 & 0,025 & $0,80 \div 1,10$ & & $\begin{array}{l}0,20 \div \\
0,35\end{array}$ & & \\
\hline 15. & 52SiCrNi5 & 1.7117 & $0,49 \div 0,56$ & $1,20 \div 1,50$ & $0,70-1,00$ & 0,025 & 0,025 & $0,70 \div 1,00$ & $\begin{array}{l}0,050 \div \\
0,070\end{array}$ & & & $\mathrm{Cu}+1$ \\
\hline 16. & $52 \mathrm{CrMoV} 4$ & 1.7701 & $0,48 \div 0,56$ & $\max 0,40$ & $0,70 \div 1,10$ & 0,025 & 0,025 & $0,70 \div 1,10$ & & $\begin{array}{l}0,15 \div \\
0,30\end{array}$ & $\begin{array}{l}0,10 \div \\
0,20 \\
\end{array}$ & $\begin{array}{l}0 \mathrm{Sn} \pm \\
0,60\end{array}$ \\
\hline 17. & 60CrMo3-1 & 1.7239 & $0,56 \div 0,64$ & $\max 0,40$ & $0,70 \div 1,00$ & 0,025 & 0,025 & $0,70-1,00$ & & $\begin{array}{l}0,06 \div \\
0,15\end{array}$ & & \\
\hline 18. & 60CrMo3-2 & 1.7240 & $0,56 \div 0,64$ & $\max 0,40$ & $0,70 \div 1,00$ & 0,025 & 0,025 & $0,70-1,00$ & & $\begin{array}{l}0,15 \div \\
0,30\end{array}$ & & \\
\hline 19. & 60CrMo3-3 & 1.7241 & $0,56 \div 0,64$ & $\max 0,40$ & $0,70 \div 1,00$ & 0,025 & 0,025 & $0,70-1,00$ & & $\begin{array}{l}0,25 \div \\
0,35\end{array}$ & & \\
\hline
\end{tabular}

- hartowanie w kapieli olejowej; temperatura hartowania musi być kontrolowana, aby tworzenie się martenzytu było pewne i całkowite;

- odpuszczanie przez czas $90 \div 120$ minut i w temperaturze ok. $400^{\circ} \mathrm{C} \div 450^{\circ} \mathrm{C} \mathrm{w}$ zależności od materiału, wytopu i wymaganej wytrzymałości (proces hartowania i odpuszczania w wysokiej temperaturze nazywa się ulepszaniem cieplnym);

- po wykonaniu odpuszczania odbywa się przeprężanie sprężyny; zabieg ten pozwala przez nadanie naprężeń przeciwnego znaku kierunku do naprężeń roboczych; wobec powyższego sprężyna może pracować tylko $\mathrm{w}$ takim kierunku w którym dokonano przeprę-żania;

- śrutowanie sprężyny, polegające na użyciu strumienia śrutu stalowego o określonym kształcie i prędkości śrutowania, mające na celu zwiększenie wytrzymałości warstwy wierzchniej sprężyny przez wytworzenie naprężeń ściskających przeciwnego znaku do obciążeń eksploatacyjnych; na rys. $1 \div 3$ pokazano rozkład naprężeń w przekroju poprzecznym podczas i po osiadaniu sprężyny oraz przy późniejszym obciążeniu eksploatacyjnym. Rys. 1 przedstawia rozkład naprężeń w przekroju poprzecznym podczas przeprężania, przy czym linia przerywana pokazuje teoretyczny przebieg naprężeń, który wynikałby $\mathrm{z}$ pełnego przebiegu sprężystego odkształcenia. Maksymalne naprężenie ściskające na krawędzi po wewnętrznej stronie jest skorygowanym naprężeniem przy zblokowaniu sprężyny $\tau_{k t b l o k}$, które określa się ze wzoru:

$$
\tau_{k t b l o k}=\tau_{F}+\tau_{e R i}
$$

gdzie:

$\tau_{\mathrm{F}} \quad$ - granica plastyczności na ścinanie

$\tau_{e R i}$ - naprężenia szczątkowe.

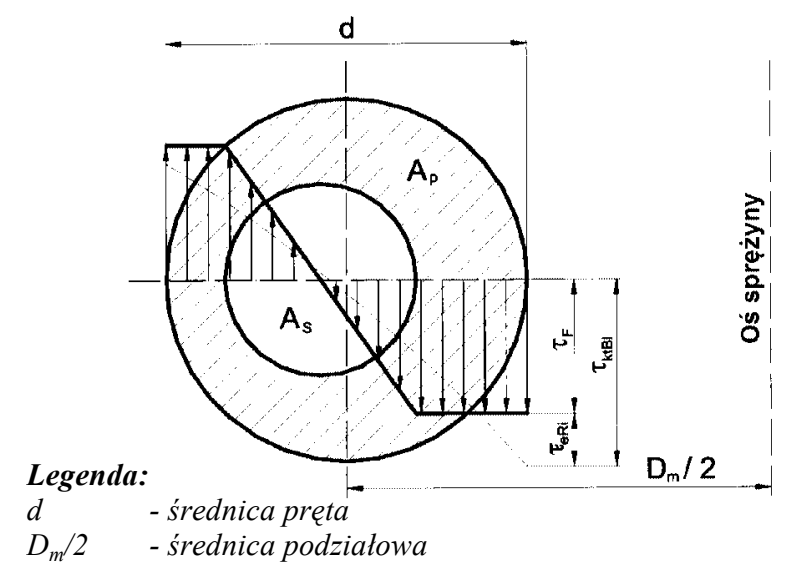

Rys. 1. Rozkład naprężeń w przekroju sprężyny śrubowej podczas operacji przeprężania 
Linia ciagła pokazuje rzeczywisty przebieg naprężeń który kończy się granicą plastyczności na ścinanie $\tau_{\mathrm{F}}$. Zakreślony obszar pod krzywą $\mathbf{A}_{\mathbf{P}}$ przedstawia zakres odkształceń plastycznych. Jeśli sprężyna jest znów odciążona i przeprężona rozkład naprężeń własnych jest przedstawiony na rys. 2 .

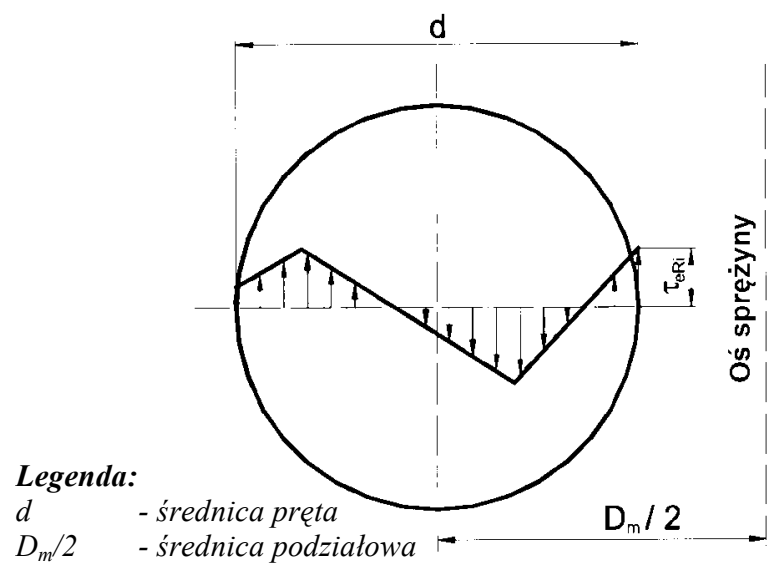

Rys.2. Rozkład naprężeń w przekroju odciążonej sprężyny śrubowej po operacji przeprężania

Rozkład naprężeń w sprężynie przeprężonej z obciążeniem eksploatacyjnym jest przedstawiony na rys.3.

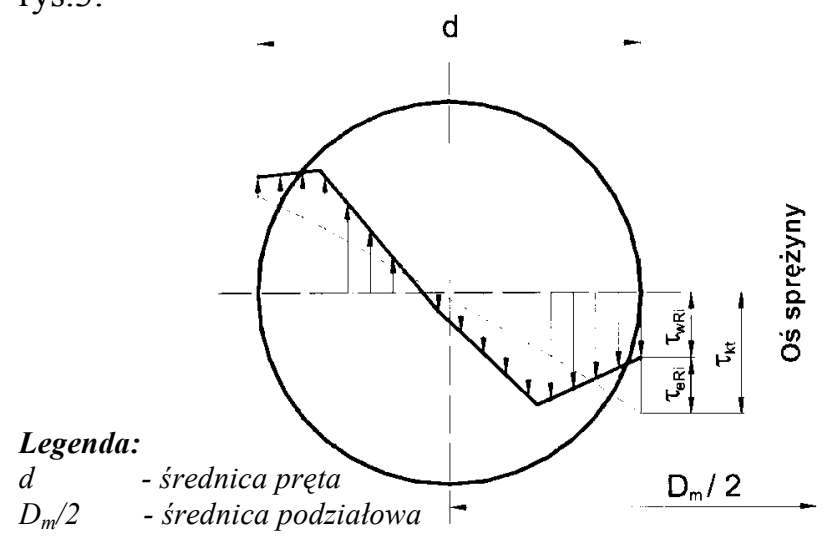

Rys.3. Rozkład naprężeń w przekroju poprzecznym sprężyny śrubowej przy obciążeniu eksploatacyjnym

Należy zwrócić uwagę na fakt, że naprężenie maksymalne na wewnętrznej krawędzi drutu sprężyny przez naprężenie własne są zredukowane wskutek naprężeń własnych, skierowanych $\mathrm{w}$ kierunku przeciwnym. W takim przypadku obowiązuje zależność:

$$
\tau_{w R i}=\tau_{k t}-\tau_{e R i}
$$

gdzie:

$\tau_{\mathrm{kt}} \quad$ - naprężenie maksymalne na wewnętrznej krawędzi pręta sprężyny, gdyby sprężyna nie była poddawana operacji przeprężania.

Naprężenia wewnętrzne $\mathrm{W}$ przeprężonej sprężynie można wyznaczyć ze wzoru:

$$
\tau_{e R i}=\tau_{k t B l}-\tau_{F}
$$

Aby proces przeprężania był efektywny należy go przeprowadzać w temperaturze $100 \div 350^{\circ} \mathrm{C}$. Efekt przeprężania sprężyny jest zależny od stosunku modu- łu Kirchoffa G (modułu na ścinanie) do granicy plastyczności na ścinanie. Stosunek ten powiększa się dla pręta ulepszonego cieplnie wraz ze wzrostem temperatury, ponieważ granica plastyczności na ścinanie szybciej obniża się, aniżeli moduł na ścinanie G.

- kontrola występowania rys (pęknięć) na powierzchni pręta sprężyny śrubowej proszkiem magnetycznym (metoda magnetoskopowa);

- szlifowanie powierzchni oparcia zwojów biernych sprężyn;

- usunięcie gratu ze szlifowanych końców sprężyn;

- malowanie sprężyn w celu zabezpieczenia antykorozyjnego;

- statyczna kontrola charakterystyk sprężyn (długość sprężyny pod obciążeniem, próby sprężystości krótkotrwałej oraz długotrwałej);

- pakowanie sprężyn.

\subsection{Uwagi do wybranych operacji technologii wy- twarzania sprężyn zawieszenia 3.2.1. Zabezpieczenie antykorozyjne}

Przedstawione ww. operacje wykonania sprężyn wpływają w różnym stopniu na żywotność sprężyn. Jednym z czynników pełniących istotna rolę jest powłoka malarska, która powinna zabezpieczyć przed korozją. Optymalna powłoka malarska powinna posiadać następujące własności [1,2]:

- wytrzymałość na odrywania, a więc być elastyczna (sprężysta), aby przejmować odkształcenia powierzchni, bez odrywania;

- dobrą przyczepność do powierzchni pręta;

- odporność na mechaniczne odkształcenia;

- dobra odporność na działanie mediów, powodujących korozję (jak np. sole i kwasy);

- możliwość zastosowania metody zanurzeniowej jako metody nanoszenia powłoki malarskiej na sprężynę;

- własności szybkoschnące;

- brak zapotrzebowania na wysokie temperatury schnięcia;

- rozpuszczalność w wodzie.

Bardzo istotnym elementem jest zastosowanie powłok malarskich rozpuszczalnych $\mathrm{w}$ wodzie, zamiast $\mathrm{w}$ rozpuszczalnikach. Jak wynika z prac studialnych przeprowadzonych przez Urząd Ochrony Środowiska w Niemczech UBA (niem. Umweltbundesamt) do środowiska naturalnego jest emitowanych jest łącznie 300000 ton organicznych środków rozpuszczalników w skali rocznej. Obok mniejszej emisji środków rozpuszczalnych należy zwrócić uwagę na mniejszą emisję powłok malarskich nie zawierających związków z metalami ciężkimi tzn. ołowiowych oraz chromowych, co przyczynia się w sposób zasadniczy do ochrony środowiska naturalnego. Należy zwrócić 
uwage na fakt, że nawet przy prawidłowo dobranej powłoce malarskiej (farba gruntowa i nawierzchniowa) może dojść do jej uszkodzenia w miejscu odległym o ok. 1 do 1,5 zwoju od końca sprężyny, gdzie dochodzi do styku zwojów w trakcie pracy dynamicznej sprężyny. W miejscu styku dochodzi w sposób wymuszony do korozji.

Brak skutecznej powłoki malarskiej, jako środka zabezpieczającego może prowadzić do pęknięć zmęczeniowych, nawet w przekrojach zwojów biernych, co jest pokazane na fotografiach, przedstawionych na rys.4 i rys.5.

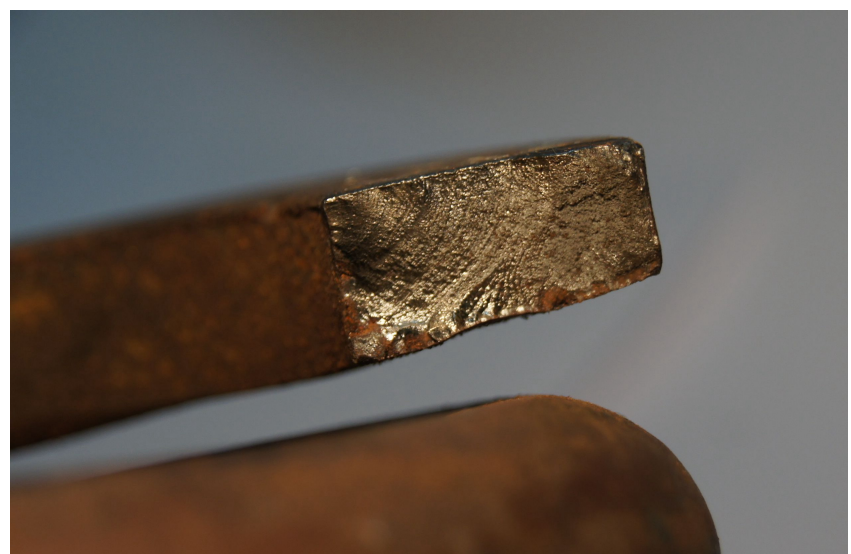

Rys. 4. Przełom zmęczeniowy na zwoju biernym wózka Y25Cs (płaszczyzna górna)

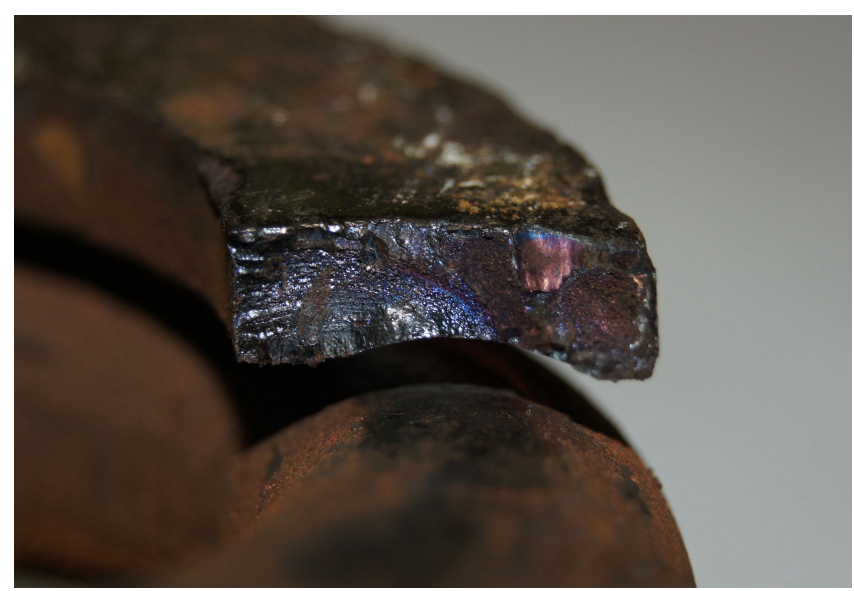

Rys. 5. Przełom zmęczeniowy na zwoju biernym wózka Y25Cs (płaszczyzna dolna)

Na rys. 4. i 5. widać poważne ślady korozji na powierzchniach zwojów biernych i czynnych sprężyn wewnętrznej. Korozja sprężyny wewnętrznej na powyższych rysunkach poczyniła znaczne postępy $\mathrm{z}$ uwagi na utratę lub zniszczenie powłoki malarskiej.

Zwoje bierne, poprawnie wykonanie, w sprężynach zawieszenia pełnią istotną rolę dla prawidłowej pracy sprężyny, a tym samym dla wytrzymałości zmęczeniowej i tak:

- prawidłowe wykonanie zwojów biernych gwarantuje dobre przyleganie do powierzchni łap maźnicy oraz do korpusu dociskacza względnie korpusu prowadnicy, co z kolei zabezpiecza prawidłowe wprowadzenie sił do sprężyny, a tym samym prawidłową jej pracę podczas eksploatacji;

- istotną rolę pełni prawidłowo wykonane znakowanie, które może być wykonane w sposób trwały tylko na powierzchni zewnętrznej zwojów biernych; przenoszenie znaków wklęsłych (wybitych stemplem) na zwoje pracujące a zwłaszcza na początek pierwszego zwoju pracującego powoduje dodatkowe spiętrzenie naprężeń i może być źródłem pęknięć zmęczeniowych w eksploatacji.

Biorąc pod uwage bardzo istotną rolę, jaką pełni powłoka malarska, badania zmęczeniowe sprężyn, zwane też badaniami trwałościowymi, należy przeprowadzać z powłokami malarskimi.

\subsubsection{Wymagania dotyczące obróbki cieplnej oraz po jej zakończeniu \\ 3.2.2.1. Obróbka cieplna}

Sprężyny poddawane są ulepszeniu cieplnemu, które składa się z dwóch procesów tzn. hartowaniu $\mathrm{w}$ wodzie lub w oleju w zależności od zastosowanego gatunku stali oraz procesu odpuszczania w wysokich temperaturach, po którym należy zapewnić powolne stygnięcie $\mathrm{w}$ spokojnym powietrzu. Zwraca się uwagę na fakt, że procesy obróbki cieplnej są tak prowadzone, aby uniknąć jakichkolwiek deformacji, natomiast odwęglenie powierzchni musi mieć charakter kontrolowany. W celu zapewnienia możliwie najlepszej jakości obróbki cieplnej zaleca się, aby ustalić wstępnie temperatury hartowania $\mathrm{i}$ odpuszczania $\mathrm{w}$ zależności od rzeczywistego składu chemicznego stali i przestrzegać tych temperatur $\mathrm{w}$ zakresie \pm 10 ?C.

\subsubsection{Odwęglenie powierzchni}

W trakcie podgrzewania sprężyny $\mathrm{w}$ celu formowania, zwijania oraz podczas hartowania i odpuszczania może dojść do odwęglenia powierzchni nośnej zwojów czynnych. Norma PN-EN 13298:2003 [13] definiuje odwegglenie (ang. decarburization, niem. Entkohlung) powierzchni pręta sprężyny jako zmniejszenie zawartości węgla podczas formowania sprężyny. Odwęglenie powierzchni nośnej powoduje lokalne zmniejszenie parametrów wytrzymałości statycznej oraz wytrzymałości zmęczeniowej (granicy zmęczenia materiału). W związku $\mathrm{z}$ powyższym należy kontrolować stopień odwęglenia, przy czym rozróżnia się dwa rodzaje stopnia odwęglenia:

- całkowite odwęlenie, gdzie warstwa powierzchniowa posiada czystą strukturę ferrytyczną;

- częściowe odwęglenie, gdzie warstwa powierzchniowa sprężyny posiada strukture ferrytyczno-perlityczną lub ferrytycznomartenzytyczną. 
Całkowite odwęglenie sprężyny jest niedopuszczalne. Zgodnie z zapisem normy europejskiej wielkość odwęglenia częściowego powierzchni może być przedmiotem uzgodnienia pomiędzy producentem a zamawiającym. O ile nie uzgodniono inaczej wielkość odwęglenia może wynosić:

- $1 \%$ średnicy ,d” sprężyny, wykonanej z prętów o przekroju okragłym;

- $\quad 1 \%$ najmniejszego średnicy pręta (zwój czynny) dla sprężyny, wykonanej $\mathrm{z}$ materiału $\mathrm{o}$ przekroju nieokragłym.

W każdym przypadku głębokość odwęglenia nie może być większa niż $0,5 \mathrm{~mm}$.

\subsubsection{Jakość powierzchni sprężyny}

Powierzchnia sprężyny nie powinna wykazywać żadnych błędów typu zawalcowania, karby, ślady obróbki, rysy lub pęknięcia. Aby osiagnąć tak wysokie wymagania, zaleca się aby pręty użyte na sprężyny nośne były obrobione mechanicznie. Zalecana chropowatość powierzchni pręta, o ile nie podano innej wartości w dokumentacji konstrukcyjnej, wynosi 2,5 $\mu \mathrm{m}$.

\subsection{4. Śrutowanie}

Śrutowanie (obróbka strumieniem kulek stalowych, niem. ,kugelstrahlen”) powinno być wykonane w warunkach ustalonych przez dokumentację konstrukcyjną (warunki techniczne wykonania i odbioru) lub w warunkach określonych przez kartę UIC 822 [10]. Kontrola skuteczności procesu śrutowania określa się na próbce Almena o wymiarach nominalnych: $76,2 \times 19 \times 1,30 \mathrm{~mm}$, która wraz ze sposobem mocowania jest przedstawiona na rys. 6 (załączniku A wg karty UIC 822 [10]).

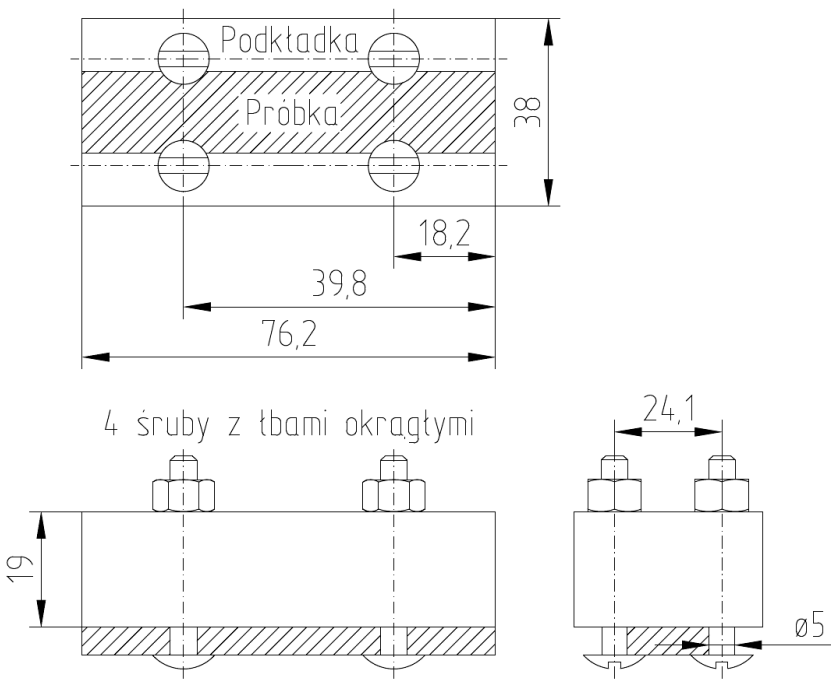

Rys. 6. Próbka Almena oraz sposób jej mocowania

Charakterystyka próbki Almena jest przedstawiona w tabeli 3 .
Charakterystyka próbki Almena do badań skuteczności umocnienia powierzchniowego Tabela 3

\begin{tabular}{|c|c|c|c|}
\hline L.p. & Wlasność & Wartość & Uwagi \\
\hline 1. & Gatunek stali & $\begin{array}{c}\text { Stal walcowana na } \\
\text { zimno }\end{array}$ & $\begin{array}{c}\text { Skład che- } \\
\text { miczny stali w } \\
\text { p. } 2 \text {. }\end{array}$ \\
\hline 2. & $\begin{array}{l}\text { Skład che- } \\
\text { miczny }\end{array}$ & $\begin{array}{c}0,65 \% \text { ? C ? } 0,73 \% \\
0,40 \% \text { ? Mn ? } 0,70 \% \\
0,15 \% \text { ? Si ? } 0,35 \% \\
\text { P ? 0, } 035 \%, \\
\text { S ? } 0,035 \%\end{array}$ & \\
\hline 3. & Długość & $76,2 \pm 0,4 \mathrm{~mm}$ & \\
\hline 4. & Szerokość & $19_{-0,1}^{+0,05} \mathrm{~mm}$ & \\
\hline 5. & Grubość & $1,30_{-0,03}^{+0,02} \mathrm{~mm}$ & \\
\hline 6. & Płaskość & $\begin{array}{c} \pm 0,04 \text { na wysokości } \\
\text { łuku }\end{array}$ & \\
\hline
\end{tabular}

Jeżeli na podkładce w kształcie bloku umocowany płaskownik stalowy jest śrutowany tylko z jednej strony, to płaskownik stalowy zostaje zgięty jeśli zdejmie się go z podkładki, przy czym powierzchnia wypukła jest stroną poddaną śrutowaniu. Powstałe przegięcie jest funkcją skutecznego strumienia śrutowania.

W ten sposób umocowana próbka jak podano na rys. 6 jest poddawana takiemu samemu cyklowi śrutowania co sprężyny, przy czym zachowane są następujące parametry:

- prędkość krążenia sprężyn w maszynie do śrutowania

- prędkość wyrzucenia śrutu stalowego

- rodzaj i wymiary śrutu stalowego.

Twardość płaskownika stalowego wynosi $62 \div 65$ HRC. Urządzenie pomiarowe ALMEN do pomiaru krzywizny próbek badanych jest przedstawione na rys.7.

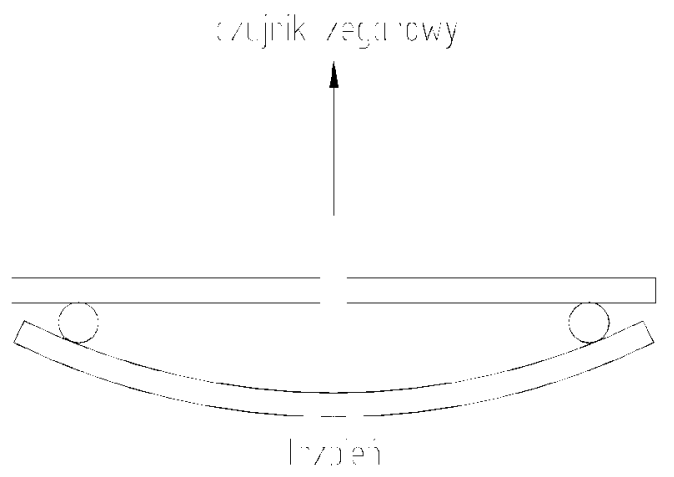

Rys. 7. Urządzenie pomiarowe do określenia krzywizny płytek badanych

Miernik służy do określenia krzywizny badanych płytek. Jest to czujnik zegarowy z tarczą i wyskalowany $z$ dokładnością $1 / 100 \mathrm{~mm}$ oraz zamontowany na stole z czterema kulkami ze stali hartowanej, tworzącymi prostokąt i umieszczonymi ściśle $\mathrm{w}$ tej samej płaszczyźnie. Trzpień znajduje się w środku prostokąta. Przesunięcie trzpienia daje miarę, która 
zależy od krzywizn poprzecznych i podłużnych próbki. Pomiar ten jest pomiarem ugięcia wklęsłej strony gładkiej $\mathrm{w}$ celu wyeliminowania wszelkich zmian, spowodowanych chropowatością powierzchni śrutowanej. Skuteczność śrutowania może być uważana jako zadawalająca jeżeli odkształcenie użytej próbki ALMEN mierzone urządzeniem pomiarowym ALMEN jest zawarte $\mathrm{w}$ przedziale $0,4 \div 0,5 \mathrm{~mm}$. Należy wziąć pod uwage, że jeśli umocnienie powierzchniowe ma zwiększyć skutecznie umocnienie powierzchniowe $(1,5 \div 1,6$ raza), to nie może być uwzględniane w obliczeniach wytrzymałościowych. Zabieg ten nie może być podważany jako skuteczny. Wątpliwości nasuwa relaksacja naprężeń w miarę upływu czasu podczas eksploatacji.

Skuteczność umocnienia powierzchniowego wykonana za pomocą procesu śrutowania zależy od następujących parametrów:

- średnicy kulek stalowych;

- prędkości śrutowania;

- kąt pochylenia do powierzchni obrabianej (kąt natarcia);

- natężenie przepływu;

- czas śrutowania.

4. Wpływ odchyłek wykonawczych na sztywność sprężyn

4.1. Wysokość sprężyny zewnętrznej pod obciążeniem

Wpływ odchyłek wykonawczych na sztywność sprężyn przeanalizowano na przykładzie sprężyny zewnętrznej wózka Y25L. Analizę wykonano w oparciu o wzór na sztywność sprężyny:

$$
\mathrm{k}_{1}=\frac{\mathrm{G} \cdot \mathrm{d}_{1}^{4}}{8 \cdot \mathrm{z}_{\mathrm{C} 1} \cdot \mathrm{D}_{1}^{3}}
$$

gdzie:

G - moduł Kirchoffa (moduł sprężystości poprzecznej);

$\mathrm{d}_{1} \quad$ - średnica drutu;

$\mathrm{D}_{1} \quad$ - średnica podziałowa;

$\mathrm{z}_{\mathrm{C} 1} \quad$ - ilość zwojów czynnych.

Jak wynika z dokumentacji konstrukcyjnej, tolerancja podatności sprężyny zewnętrznej wynosi $\mathrm{c}_{1}=20 \pm 1,6 \quad \mathrm{~mm} / 1000 \quad \mathrm{daN} \quad(\mathrm{c}=19,69 \pm 1,57 \mathrm{~mm} / 1000$ $\mathrm{kG}$ ). Sprężyna ma wysokość tolerowaną pod obciążeniem 880 daN, które odpowiada masie wagonu czteroosiowego o masie $20000 \mathrm{~kg}$ na wózkach Y25Lsd i wynosi ona $242_{-3}^{+1} \quad \mathrm{~mm} \quad\left(\mathrm{H}_{1 \mathrm{MIN}}=239 \mathrm{~mm}\right.$ oraz $\mathrm{H}_{2 \mathrm{MAX}}=243 \mathrm{~mm}$ ). Wysokość sprężyny, która wynika $\mathrm{z}$ rozrzutu podatności wynoszącej $+8 \%$ wynosi odpowiednio:

$$
\mathrm{H}_{\mathrm{PRÓZNY} 1}=\mathrm{H}-\mathrm{c}_{1} \cdot \mathrm{P}_{1}
$$

Po wstawieniu danych liczbowych $\mathrm{H}=260$ $\mathrm{mm}, \mathrm{c}_{1}=21,6 \mathrm{~mm} / 1000 \mathrm{daN}$ oraz $\mathrm{P}_{1}=880 \mathrm{daN}$ otrzymuje się

$$
\mathrm{H}_{\text {PRÓZNY1 }}=260-\frac{21,6 \cdot 880}{1000}=240,99 \mathrm{~mm}
$$

Po wstawieniu danych liczbowych $\mathrm{H}=260$ $\mathrm{mm}, \mathrm{c}_{1}=18,4 \mathrm{~mm} / 1000 \mathrm{daN}$ oraz $\mathrm{P}_{1}=880 \mathrm{daN}$ otrzymuje się:

$$
\mathrm{H}_{\text {PRÓZNY1 }}=260-\frac{18,4 \cdot 880}{1000}=243,808 \mathrm{~mm}
$$

W przypadku nominalnej wartości podatności „c", wynoszącej $\mathrm{c}_{\mathrm{NOM}}=20 \mathrm{~mm} / 1000$ daN otrzymuje się:

$$
\mathrm{H}_{\text {PRÓZNY1 }}=260-\frac{20 \cdot 880}{1000}=242,4 \mathrm{~mm}
$$

Jak widać z powyższych obliczeń, rozrzut podatności $\pm 8 \%$ gwarantuje $\mathrm{z}$ pewnym zastrzeżeniem osiagnięcie wymiaru $242_{-3}^{+1}$, pod obciążeniem 880 daN.

\subsection{Wpływ odchyłek na sztywność sprężyny wy- znaczony metodą Langrange'a oraz metodą arytmetyczną}

Aby wyznaczyć wpływ odchyłek na sztywność (podatność) sprężyny zewnętrznej wyliczono pierwszą pochodną złożoną, jako sumę pochodnych cząstkowych. Funkcję odchyłek sztywności jako pochodna cząstkowa wyznacza się ze wzoru:

$$
\mathrm{t}_{\mathrm{k}}=\left|\frac{\partial \mathrm{k}}{\partial \mathrm{d}_{1}} \cdot \mathrm{t}_{\mathrm{d} 1}\right|+\left|\frac{\partial \mathrm{k}}{\partial \mathrm{D}_{1}} \cdot \mathrm{t}_{\mathrm{D}_{1}}\right|+\left|\frac{\partial \mathrm{k}}{\partial \mathrm{z}_{\mathrm{c}}} \cdot \mathrm{t}_{\mathrm{zc}}\right|
$$

Poszczególne pochodne cząstkowe wynoszą odpowiednio:

$$
\begin{aligned}
\frac{\partial \mathrm{k}}{\partial \mathrm{d}_{1}} & =\frac{4 \cdot \mathrm{G} \cdot \mathrm{d}_{1}^{3}}{8 \cdot \mathrm{D}_{1}^{3} \cdot \mathrm{z}_{\mathrm{c} 1}} \\
\frac{\partial \mathrm{k}}{\partial \mathrm{D}_{1}} & =-\frac{3 \cdot \mathrm{G} \cdot \mathrm{d}_{1}^{4}}{8 \cdot \mathrm{D}_{1}^{4} \cdot \mathrm{z}_{\mathrm{c} 1}} \\
\frac{\partial \mathrm{k}}{\partial \mathrm{z}_{\mathrm{C} 1}} & =-\frac{\mathrm{G} \cdot \mathrm{d}_{1}^{4}}{8 \cdot \mathrm{D}_{1}^{3} \cdot \mathrm{z}_{\mathrm{c} 1}^{2}}
\end{aligned}
$$

$\mathrm{W}$ dalszej kolejności poszukiwano wartości optymalnych $\mathrm{D}_{1} \mathrm{i} \mathrm{d}_{1}$, natomiast ilość zwojów $\mathrm{z}_{\mathrm{C}}$ przyjęto jako wielkość, wynikająca z warunku założonej sztywności „, $\mathrm{k}_{0}$ ”. Przekształcając wzór (4) otrzymuje się:

$$
\mathrm{z}_{\mathrm{C}}=\frac{\mathrm{G} \cdot \mathrm{d}^{4}}{8 \cdot \mathrm{D}^{3} \cdot \mathrm{k}_{0}}
$$

Po wstawieniu wartości liczbowych do wzoru (13) tzn. $\mathrm{G}=7850 \mathrm{daN} / \mathrm{mm}^{2}$ oraz $\mathrm{k}=49,82 \mathrm{daN} / \mathrm{mm}$ otrzymuje się:

$$
\mathrm{z}_{\mathrm{C} 1}=\frac{7850 \cdot \mathrm{d}_{1}^{4}}{8 \cdot 49,82 \cdot \mathrm{D}_{1}^{3}}
$$

Po wstawieniu wyrazu (13) do równań (10), (11) oraz (12) otrzymuje się: 


$$
\begin{gathered}
\frac{\partial \mathrm{k}_{0}}{\partial \mathrm{d}_{1}}=\frac{4 \cdot \mathrm{G} \cdot \mathrm{d}_{1}^{3}}{8 \cdot \mathrm{D}_{1}^{3} \cdot \frac{\mathrm{G} \cdot \mathrm{d}_{1}^{4}}{8 \cdot \mathrm{D}_{1}^{3} \cdot \mathrm{k}_{0}}}=\frac{4 \mathrm{k}_{0}}{\mathrm{~d}_{1}} \\
\frac{\partial \mathrm{k}_{0}}{\partial \mathrm{D}_{1}}=-\frac{3 \cdot \mathrm{G} \cdot \mathrm{d}_{1}^{4}}{8 \cdot \mathrm{D}_{1}^{4} \cdot \frac{\mathrm{G} \cdot \mathrm{d}_{1}^{4}}{8 \cdot \mathrm{D}_{1}^{3} \cdot \mathrm{k}_{0}}}=-\frac{3 \mathrm{k}_{0}}{\mathrm{D}_{1}} \\
\frac{\partial \mathrm{k}_{0}}{\partial \mathrm{z}_{\mathrm{Cl}}}=-\frac{\mathrm{G} \cdot \mathrm{d}_{1}^{4}}{8 \cdot \mathrm{D}_{1}^{3} \cdot\left(\frac{\mathrm{G} \cdot \mathrm{d}_{1}^{4}}{8 \cdot \mathrm{D}_{1}^{3} \cdot \mathrm{k}_{0}}\right)^{2}}=\frac{8 \cdot \mathrm{D}_{1}^{3} \cdot \mathrm{k}_{0}^{2}}{\mathrm{G} \cdot \mathrm{d}_{1}^{4}} \\
\mathrm{t}_{\mathrm{k}}=\frac{4 \mathrm{k}_{0}}{\mathrm{~d}_{1}} \cdot \mathrm{t}_{\mathrm{d} 1}+\frac{3 \mathrm{k}_{0}}{\mathrm{D}_{1}} \cdot \mathrm{t}_{\mathrm{D} 1}+\frac{8 \cdot \mathrm{D}_{1}^{3} \cdot \mathrm{k}_{0}^{2}}{\mathrm{G} \cdot \mathrm{d}_{1}^{4}} \cdot \mathrm{t}_{\mathrm{n} 1}
\end{gathered}
$$

Po wstawieniu danych liczbowych do wzoru (18) tzn. $\mathrm{k}_{0}=49,82 \mathrm{daN} / \mathrm{mm}, \mathrm{d}_{1}=31 \mathrm{~mm}, \mathrm{t}_{\mathrm{d} 1}=0,31 \mathrm{~mm}$, $\mathrm{D}_{1}=163^{+1,5} \mathrm{~mm}, \mathrm{G}=7850 \mathrm{daN} / \mathrm{mm}^{2}$ oraz $\mathrm{t}_{\mathrm{n}}=0,1$ zwoju otrzymuje się odchyłkę dodatnią sztywności sprężyny zewnętrznej:

$$
+t_{k}=\frac{4 \cdot 49,82}{31} \cdot 0,31+\frac{3 \cdot 49,82}{163} \cdot 1,5+\frac{8 \cdot 163^{3} \cdot(49,82)^{2}}{7850 \cdot 31^{4}} \cdot 0,1
$$

$$
+\mathrm{t}_{\mathrm{k}}=1,9928+1,3753+1,1861=4,5514 \mathrm{daN} / \mathrm{mm}
$$

Po wstawieniu danych liczbowych do wzoru (18) tzn. $\mathrm{k}_{0}=49,82 \mathrm{daN} / \mathrm{mm}, \mathrm{d}_{1}=31 \mathrm{~mm}, \mathrm{t}_{\mathrm{d} 1}=0,31 \mathrm{~mm}$, $\mathrm{D}_{1}=163^{+2} \mathrm{~mm}, \mathrm{G}=7850 \mathrm{daN} / \mathrm{mm}^{2}$ oraz $\mathrm{t}_{\mathrm{n}}=0,1$ zwoju otrzymuje się odchyłkę ujemną sztywności sprężyny zewnętrznej:

$$
\begin{aligned}
& -t_{k}=-\frac{4 \cdot 49,82}{31} \cdot 0,31-\frac{3 \cdot 49,82}{163} \cdot 2-\frac{8 \cdot 163^{3} \cdot(49,82)^{2}}{7850 \cdot 31^{4}} \cdot 0,1 \\
& -t_{k}=-1,9928-1,833-1,1861=-5,009 \mathrm{daN} / \mathrm{mm}
\end{aligned}
$$

Tolerancja sztywności sprężyny zewnętrznej zgodnie z rozkładem Gaussa wynosi więc:

$$
\mathrm{k}_{0}=49,82_{-5,009}^{+4,5514} \mathrm{daN} / \mathrm{mm}
$$

Ww. odchyłki sztywności w przeliczeniu procentowym przedstawiają się następująco:

$$
\mathrm{k}_{0}=49,82_{-10,05 \%}^{+9,13 \%} \mathrm{daN} / \mathrm{mm}
$$

$\mathrm{Z}$ przedstawionych obliczeń, wynikających ze skrajnych odchyłek wykonawczych tzn. $\mathrm{d}=31 \pm 0,31 \mathrm{~mm}, \quad \mathrm{D}=163_{-1,5}^{+2} \mathrm{~mm}$ oraz $\quad \mathrm{z}_{\mathrm{C}}= \pm 0,1$ zwoja wynika, że najmniejsza tolerancja sztywności sprężyny zewnętrznej przy skrajnych odchyłkach wykonawczych wynosi:

$$
\mathrm{k}_{\mathrm{MIN}}=44,81 \mathrm{daN} / \mathrm{mm}
$$

Największa tolerancja sztywności przy skrajnych odchyłkach wykonawczych wynosi:

$$
\mathrm{k}_{\mathrm{MAX}}=54,37 \mathrm{daN} / \mathrm{mm}
$$

Rachunek sprawdzający można wykonać w oparciu o metodę arytmetyczną:

$$
\mathrm{k}_{\mathrm{MIN}}=\frac{7850 \cdot(31-0,31)^{4}}{8 \cdot(163+2)^{3} \cdot 4,3}=45,06 \mathrm{daN} / \mathrm{mm}
$$

$\mathrm{k}_{\mathrm{MAX}}=\frac{7850 \cdot(31+0,31)^{4}}{8 \cdot(163-1,5)^{3} \cdot 4,1}=54,60 \mathrm{daN} / \mathrm{mm}$

Wartości sztywności sprężyny zewnętrznej, wyznaczone metodą Langrange'a (wzory (25) oraz (26)) oraz metodą arytmetyczną (wzory (27) oraz (28)) są zbliżone, co dowodzi poprawności wykonanych obliczeń.

Tolerancja sztywności otrzymana metodą arytmetyczną wynosi:

$$
\mathrm{k}_{0}=49,82_{-4,76}^{+4,78} \mathrm{daN} / \mathrm{mm}
$$

Tolerancja sztywności wyrażona $\mathrm{w}$ procentach wynosi:

$$
\mathrm{k}_{0}=49,82_{-9,55 \%}^{+9,59 \%} \mathrm{daN} / \mathrm{mm}
$$

\subsection{Wpływ odchyłek na sztywność sprężyny wy- znaczony metodą statystyczną}

Zakładając, że odchyłki są zgodne z rozkładem statystycznym Gaussa (rozkładem normalnym) sztywność można wyznaczyć z następującej zależności:

$$
\mathrm{k}_{\text {OSTAT }}=\mathrm{k}_{0}-\mathrm{k}_{\mathrm{M}} \pm \frac{\mathrm{T}_{\mathrm{N}}}{2}
$$

gdzie:

$\mathrm{k}_{\mathrm{M}} \quad$ - współczynnik skośności,

$\mathrm{k}_{0} \quad$ - sztywność nominalna

$\mathrm{T}_{\mathrm{M}} \quad$ - tolerancja wynikowa

Współczynnik skośności (asymetrii) wyraża się wzorem:

$$
\mathrm{k}_{\mathrm{M}}=\frac{\partial \mathrm{k}}{\partial \mathrm{D}} \cdot \frac{\left(\mathrm{D}_{11}+\mathrm{D}_{12}\right)}{2}=\frac{3 \mathrm{k}_{0}}{\mathrm{D}_{1}} \frac{(2-1,5)}{2}
$$

Po wstawieniu danych liczbowych do wzoru (32) tzn. $\mathrm{k}_{0}=49,82 \mathrm{daN} / \mathrm{mm}, \mathrm{D}_{1}=163 \mathrm{~mm}$, $\mathrm{D}_{11}=2 \mathrm{~mm}$ oraz $\mathrm{D}_{12}=1,5 \mathrm{~mm}$ otrzymuje się:

$\mathrm{k}_{\mathrm{M}}=\frac{\partial \mathrm{k}}{\partial \mathrm{D}} \cdot \frac{\left(\mathrm{D}_{11}+\mathrm{D}_{12}\right)}{2}=\frac{3 \cdot 49,82}{163} \frac{(2-1,5)}{2}=0,2292 \mathrm{daN} / \mathrm{mm}$

Tolerancję wyznacza się ze wzoru:

$$
\mathrm{T}_{\mathrm{N}}=\sqrt{\left(\frac{\partial \mathrm{k}}{\partial \mathrm{d}_{1}} \cdot \mathrm{t}_{\mathrm{d}} \times 2\right)^{2}+\left(\frac{\partial \mathrm{k}}{\partial \mathrm{D}_{1}} \cdot\left(\mathrm{t}_{\mathrm{D} 1}+\mathrm{t}_{\mathrm{D} 2}\right)\right)^{2}+\left(\frac{\partial \mathrm{k}}{\partial \mathrm{z}_{\mathrm{cl}}} \cdot 2 \mathrm{z}_{\mathrm{C} 1}\right)^{2}}
$$

Wstawiając dane liczbowe do wzoru (34), a więc:

$$
\begin{aligned}
\frac{\partial \mathrm{k}_{0}}{\partial \mathrm{d}_{1}} & =\frac{4 \mathrm{k}_{0}}{\mathrm{~d}_{1}}=\frac{4 \cdot 49,82}{31}=6,4283 \mathrm{daN} / \mathrm{mm}^{2} \\
\frac{\partial \mathrm{k}_{0}}{\partial \mathrm{D}_{1}} & =-\frac{3 \mathrm{k}_{0}}{\mathrm{D}_{1}}=-\frac{3 \cdot 49,82}{163}=-0,9169 \mathrm{daN} / \mathrm{mm}^{2} \\
\frac{\partial \mathrm{k}_{0}}{\partial \mathrm{z}_{\mathrm{Cl}}} & =-\frac{8 \cdot \mathrm{D}_{1}^{3} \cdot \mathrm{k}_{0}^{2}}{\mathrm{G} \cdot \mathrm{d}_{1}^{4}}=\frac{8 \cdot 163^{3} \cdot 49,82^{2}}{7850 \cdot 31^{4}}=-11,8616 \mathrm{daN} / \mathrm{mm}
\end{aligned}
$$

Po wstawieniu danych liczbowych $t_{d}=0,31$ $\mathrm{mm}, \mathrm{t}_{\mathrm{D} 1}+\mathrm{t}_{\mathrm{D} 2}=3,5 \mathrm{~mm}$ oraz $\mathrm{z}_{\mathrm{cl}}=0,1$ zwoju do równania (34) otrzymuje się: 


$$
\mathrm{T}_{\mathrm{N}}=\sqrt{(6,4283 \cdot 0,31 \times 2)^{2}+(0,9169 \cdot 3,5)^{2}+(11,861 \cdot 2 \cdot 0,1)^{2}}=5,640 \mathrm{~mm}
$$

Wstawiając dane liczbowe, otrzymane ze wzorów (33) i (38) do wzoru (31) otrzymuje się:

$$
\mathrm{k}_{\text {OSTAT }}=49,82-0,2292 \pm 0,5 \cdot 5,640=49,59 \pm 2,82 \mathrm{daN} / \mathrm{mm}
$$
wiednio:

Sztywność statystyczna minimalna oraz maksymalna sprężyny zewnętrznej wynosi odpo-

$$
\begin{aligned}
& \mathrm{k}_{\text {OSTATMIN }}=46,77 \mathrm{daN} / \mathrm{mm} \\
& \mathrm{k}_{\text {OSTATMAX }}=52,41 \mathrm{daN} / \mathrm{mm}
\end{aligned}
$$

Obliczając odchyłki górne i dolne w sposób niezależny otrzymuje się:

$$
\mathrm{t}_{\mathrm{G}}=\sqrt{\left(\frac{\partial \mathrm{k}}{\partial \mathrm{d}_{1}} \cdot \mathrm{t}_{\mathrm{d} 1}\right)^{2}+\left(\frac{\partial \mathrm{k}}{\partial \mathrm{D}_{1}} \cdot\left(\mathrm{t}_{\mathrm{DGl}}\right)\right)^{2}+\left(\frac{\partial \mathrm{k}}{\partial \mathrm{z}_{\mathrm{cl}}} \cdot \mathrm{t}_{\mathrm{zCl}}\right)^{2}}
$$

oraz

$$
\mathrm{t}_{\mathrm{G}}=\sqrt{\left(\frac{\partial \mathrm{k}}{\partial \mathrm{d}_{1}} \cdot \mathrm{t}_{\mathrm{d} 1}\right)^{2}+\left(\frac{\partial \mathrm{k}}{\partial \mathrm{D}_{1}} \cdot\left(\mathrm{t}_{\mathrm{DD}}\right)\right)^{2}+\left(\frac{\partial \mathrm{k}}{\partial \mathrm{z}_{\mathrm{cl}}} \cdot \mathrm{t}_{\mathrm{zCl}}\right)^{2}}
$$

Wstawiając dane liczbowe do wzoru (41) oraz (42) otrzymuje się odpowiednio:

$$
t_{G}=\sqrt{(6,4283 \cdot 0,31)^{2}+(0,9169 \cdot 1,5)^{2}+(11,861 \cdot 0,1)^{2}}=2,6962 \mathrm{daN} / \mathrm{mm}
$$

oraz

$$
\mathrm{t}_{\mathrm{D}}=\sqrt{(6,4283 \cdot 0,31)^{2}+(0,9169 \cdot 2)^{2}+(11,861 \cdot 0,1)^{2}}=2,9564 \mathrm{daN} / \mathrm{mm}
$$

Tolerancja statystyczna, jako suma odchyłek $\mathrm{t}_{\mathrm{G}}$ oraz $\mathrm{t}_{\mathrm{D}}$ wynosi odpowiednio:

$$
\mathrm{T}_{\mathrm{N}}=\mathrm{t}_{\mathrm{D}}+\mathrm{t}_{\mathrm{G}}=2,9564+2,6962=5,6526 \mathrm{daN} / \mathrm{mm}
$$
wiednio:

Sztywność statystyczna minimalna oraz maksymalna sprężyny zewnętrznej wynosi odpo-

$$
\begin{aligned}
& \mathrm{k}_{\text {OSTATMAX }}=\mathrm{k}_{\mathrm{O}}+\mathrm{t}_{\mathrm{G}}=49,82+2,6962=52,51 \mathrm{daN} / \mathrm{mm} \\
& \mathrm{k}_{\text {OSTATMIN }}=\mathrm{k}_{\mathrm{O}}-\mathrm{t}_{\mathrm{D}}=49,82-2,9564=46,86 \mathrm{daN} / \mathrm{mm}
\end{aligned}
$$

Wartości te (wzory (47) i (48)) są zbliżone do wartości sztywności sprężyny zewnętrznej, przedstawionych we wzorach (39) oraz (40), co dowodzi poprawności przeprowadzonych obliczeń.

Tolerancje sztywności wyrażone procentowo w stosunku do wartości nominalnej wynoszą odpowiednio:

$$
\mathrm{k}_{\text {OSTAT }}=49,82_{-2,9564}^{+2,6962}=49,82_{-5,93 \%}^{+5,41 \%} \mathrm{daN} / \mathrm{mm}
$$

Podatność nominalna sprężyny zewnętrznej wynikająca ze wzoru (49) wynosi odpowiednio:

$$
\mathrm{c}_{\mathrm{O}}=20,07 \mathrm{~mm} / 1000 \mathrm{daN}
$$

Podatność minimalna sprężyny zewnętrznej w ujęciu statystycznym wynosi odpowiednio:

$$
\mathrm{c}_{\text {OSTATMIN }}=19,04 \mathrm{~mm} / 1000 \mathrm{daN}
$$

Podatność maksymalna sprężyny zewnętrznej w ujęciu statystycznym wynosi odpowiednio:

$$
\mathrm{c}_{\text {OSTATMIN }}=21,34 \mathrm{~mm} / 1000 \mathrm{daN}
$$

Przedstawiając zależności (48), (49) oraz (51) w formie odchyłek od wartości nominalnej otrzymuje się zależność:

$$
\mathrm{c}_{\text {OSTAT }}=20,07_{-1,03}^{+1,27} \mathrm{~mm} / 1000 \mathrm{daN}
$$
zależność:

Wyrażając odchyłki podatności w formie procentowej od wartości nominalnej otrzymuje się

$$
\mathrm{c}_{\text {OSTAT }}=20,07_{-5,13 \%}^{+6,32 \%} \mathrm{~mm} / 1000 \mathrm{daN}
$$

Jak widać z przeprowadzonej analizy, w przypadku założenia, że odchyłki mające wpływ na podatność (sztywność) drutu mają rozkład losowy zgodny z rozkładem normalnym, to wówczas warunek tolerancji podatności, założonej $\mathrm{w}$ zakresie $\pm 8 \%$ wartości nominalnej, jest spełniony $\mathrm{z}$ dużą rezerwą. 


\subsection{Wpływ zaostrzonych odchyłek wykonawczych na sztywność sprężyny wyznaczony metodą Langrange'a}

Zakładając, że sprężyna zewnętrzna jest wykonana z drutu szlifowanego to wtedy odchyłki średnicy pręta wynoszą $Ø 31 \pm 0,1 \mathrm{~mm}$ oraz założono tolerancję wykonania liczby zwojów, wynoszącą $4,2 \pm 0,05$ zwoju.

Po wstawieniu danych liczbowych do wzoru (18) tzn. $\mathrm{k}_{0}=49,82 \mathrm{daN} / \mathrm{mm}, \mathrm{d}_{1}=31 \mathrm{~mm}, \mathrm{t}_{\mathrm{dl}}=0,1$ $\mathrm{mm} \mathrm{mm}, \mathrm{D}_{1}=163^{+1,5} \mathrm{~mm}, \mathrm{G}=7850 \mathrm{daN} / \mathrm{mm}^{2}$ oraz $\mathrm{t}_{\mathrm{n}}=0,05$ zwoja otrzymuje się odchyłkę dodatnią sztywności sprężyny zewnętrznej:

$$
\begin{gathered}
+t_{k}=\frac{4 \cdot 49,82}{31} \cdot 0,1+\frac{3 \cdot 49,82}{163} \cdot 1,5+\frac{8 \cdot 163^{3} \cdot(49,82)^{2}}{7850 \cdot 31^{4}} \cdot 0,05 \\
+t_{k}=0,6428+1,3753+0,593=2,611 \mathrm{daN} / \mathrm{mm}
\end{gathered}
$$

Po wstawieniu danych liczbowych do wzoru (18) tzn. $\mathrm{k}_{0}=49,82 \mathrm{daN} / \mathrm{mm}, \mathrm{d}_{1}=31 \mathrm{~mm}, \mathrm{t}_{\mathrm{d} 1}=0,1$ $\mathrm{mm}, \mathrm{D}_{1}=163^{+2} \mathrm{~mm}, \mathrm{G}=7850 \mathrm{daN} / \mathrm{mm}^{2}$ oraz $\mathrm{t}_{\mathrm{n}}=0,05$ zwoju otrzymuje się odchyłkę ujemną sztywności sprężyny zewnętrznej:

$$
\begin{gathered}
-t_{k}=-\frac{4 \cdot 49,82}{31} \cdot 0,1-\frac{3 \cdot 49,82}{163} \cdot 2-\frac{8 \cdot 163^{3} \cdot(49,82)^{2}}{7850 \cdot 31^{4}} \cdot 0,05 \\
-t_{k}=-0,6428-1,833-0,593=-3,0688 \mathrm{daN} / \mathrm{mm}
\end{gathered}
$$

Tolerancja sztywności sprężyny zewnętrznej zgodnie z rozkładem Gaussa wynosi więc:

$$
\mathrm{k}_{0}=49,82_{-3,0688}^{+2,611} \mathrm{daN} / \mathrm{mm}
$$

Ww. odchyłki sztywności w przeliczeniu procentowym przedstawiają się następująco:

$$
\mathrm{k}_{0}=49,82_{-6,15 \%}^{+5,24 \%} \mathrm{daN} / \mathrm{mm}
$$

Z przedstawionych obliczeń, wynikających ze skrajnych odchyłek wykonawczych tzn. $\mathrm{d}=31 \pm 0,1 \mathrm{~mm}, \mathrm{D}=163_{-1,5}^{+2} \mathrm{~mm}$ oraz $\mathrm{z}_{\mathrm{C}}= \pm 0,05$ zwoja wynika, że najmniejsza tolerancja sztywności sprężyny zewnętrznej przy skrajnych odchyłkach wykonawczych wynosi:

$$
\mathrm{k}_{\mathrm{MIN}}=46,75 \mathrm{daN} / \mathrm{mm}
$$

Największa tolerancja sztywności przy skrajnych odchyłkach wykonawczych wynosi:

$$
\mathrm{k}_{\mathrm{MAX}}=52,43 \mathrm{daN} / \mathrm{mm}
$$

Rachunek sprawdzający można wykonać w oparciu o metodę arytmetyczną:

$$
\begin{aligned}
\mathrm{k}_{\mathrm{MIN}} & =\frac{7850 \cdot(31-0,1)^{4}}{8 \cdot(163+2)^{3} \cdot 4,25}=46,85 \mathrm{daN} / \mathrm{mm} \\
\mathrm{k}_{\mathrm{MAX}} & =\frac{7850 \cdot(31+0,1)^{4}}{8 \cdot(163+1,5)^{3} \cdot 4,15}=52,51 \mathrm{daN} / \mathrm{mm}
\end{aligned}
$$

Wartości sztywności sprężyny zewnętrznej wyznaczone metodą Langrange’a (wzory (61) oraz (62)) oraz metodą arytmetyczną (wzory (63) oraz (64)) są zbliżone, co dowodzi poprawności wykonanych obliczeń.

Tolerancja sztywności otrzymana metodą arytmetyczną wynosi odpowiednio:

$$
\mathrm{k}_{0}=49,82_{-2,97}^{+2,69} \mathrm{daN} / \mathrm{mm}
$$

Tolerancja sztywności wyrażona w procentach wynosi odpowiednio:

$$
\mathrm{k}_{0}=49,82_{-5,96 \%}^{+5,39 \%} \mathrm{daN} / \mathrm{mm}
$$

\subsection{Wpływ zaostrzonych odchyłek wykonawczych na sztywność sprężyny wyznaczony metodą statystyczną}

Po wstawieniu danych liczbowych $t_{d}=0,1 \mathrm{~mm}, \mathrm{t}_{\mathrm{D} 1}+\mathrm{t}_{\mathrm{D} 2}=3,5 \mathrm{~mm}$ oraz $\mathrm{t}_{\mathrm{cl}}=0,05$ zwoju do równania (34) otrzymuje się:

$$
\mathrm{T}_{\mathrm{N}}=\sqrt{(6,4283 \cdot 0,1 \times 2)^{2}+(0,9169 \cdot 3,5)^{2}+(11,861 \cdot 2 \cdot 0,05)^{2}}=3,654 \mathrm{~mm}
$$

Wstawiając dane liczbowe, otrzymane ze wzorów (33) i (67) do wzoru (31) otrzymuje się: 


$$
\mathrm{k}_{\text {OSTAT }}=49,82-0,2292 \pm 0,5 \cdot 3,654=49,59 \pm 1,827 \mathrm{daN} / \mathrm{mm}
$$

Sztywność statystyczna minimalna oraz maksymalna sprężyny zewnętrznej wynosi odpowiednio:

$$
\begin{aligned}
& \mathrm{k}_{\text {OSTATMIN }}=51,417 \mathrm{daN} / \mathrm{mm} \\
& \mathrm{k}_{\text {OSTATMAX }}=47,763 \mathrm{daN} / \mathrm{mm}
\end{aligned}
$$

Obliczając odchyłki górne i dolne w sposób niezależny otrzymuje się:

$$
\mathrm{t}_{\mathrm{G}}=\sqrt{\left(\frac{\partial \mathrm{k}}{\partial \mathrm{d}_{1}} \cdot \mathrm{t}_{\mathrm{d} 1}\right)^{2}+\left(\frac{\partial \mathrm{k}}{\partial \mathrm{D}_{1}} \cdot\left(\mathrm{t}_{\mathrm{DG} 1}\right)\right)^{2}+\left(\frac{\partial \mathrm{k}}{\partial \mathrm{z}_{\mathrm{c} 1}} \cdot \mathrm{t}_{\mathrm{ZC} 1}\right)^{2}}
$$

oraz

$$
\mathrm{t}_{\mathrm{D}}=\sqrt{\left(\frac{\partial \mathrm{k}}{\partial \mathrm{d}_{1}} \cdot \mathrm{t}_{\mathrm{d} 1}\right)^{2}+\left(\frac{\partial \mathrm{k}}{\partial \mathrm{D}_{1}} \cdot\left(\mathrm{t}_{\mathrm{DD} 1}\right)\right)^{2}+\left(\frac{\partial \mathrm{k}}{\partial \mathrm{z}_{\mathrm{c} 1}} \cdot \mathrm{t}_{\mathrm{ZC} 1}\right)^{2}}
$$

Wstawiając dane liczbowe do wzoru (71) oraz (72) otrzymuje się odpowiednio:

$$
\mathrm{t}_{\mathrm{G}}=\sqrt{(6,4283 \cdot 0,1)^{2}+(0,9169 \cdot 1,5)^{2}+(11,861 \cdot 0,05)^{2}}=1,6298 \mathrm{daN} / \mathrm{mm}
$$

oraz

$$
t_{D}=\sqrt{(6,4283 \cdot 0,1)^{2}+(0,9169 \cdot 2)^{2}+(11,861 \cdot 0,05)^{2}}=2,031 \mathrm{daN} / \mathrm{mm}
$$

Tolerancja statystyczna, jako suma odchyłek $\mathrm{t}_{\mathrm{G}}$ oraz $\mathrm{t}_{\mathrm{D}}$ wynosi odpowiednio:

$$
\mathrm{T}_{\mathrm{N}}=\mathrm{t}_{\mathrm{D}}+\mathrm{t}_{\mathrm{G}}=1,6298+2,031=3,6608 \mathrm{daN} / \mathrm{mm}
$$
wiednio:

Sztywność statystyczna minimalna oraz maksymalna sprężyny zewnętrznej wynosi odpo-

$$
\begin{aligned}
& \mathrm{k}_{\text {OSTATMAX }}=\mathrm{k}_{\mathrm{O}}+\mathrm{t}_{\mathrm{G}}=49,82+1,6298=51,44 \mathrm{daN} / \mathrm{mm} \\
& \mathrm{k}_{\text {OSTATMIN }}=\mathrm{k}_{\mathrm{O}}-\mathrm{t}_{\mathrm{D}}=49,82-2,031=47,789 \mathrm{daN} / \mathrm{mm}
\end{aligned}
$$

Wartości te (wzory (76) i (77)) są zbliżone do tych wartości sztywności sprężyny zewnętrznej, które są przedstawione we wzorach (69) oraz (70), co dowodzi poprawności przeprowadzonych obliczeń.

Tolerancje sztywności wyrażone procentowo w stosunku do wartości nominalnej wynoszą odpowiednio:

$$
\mathrm{k}_{\text {OSTAT }}=49,82_{-2,031}^{+1,6298} \mathrm{daN} / \mathrm{mm}=49,82_{-4,07 \%}^{+3,27 \%} \mathrm{daN} / \mathrm{mm}
$$

Podatność nominalna sprężyny zewnętrznej wynikająca ze wzoru (49) wynosi odpowiednio:

$$
\mathrm{c}_{\mathrm{O}}=20,07 \mathrm{~mm} / 1000 \mathrm{daN}
$$

Podatność minimalna sprężyny zewnętrznej w ujęciu statystycznym wynosi odpowiednio:

$$
\mathrm{c}_{\text {OSTATMIN }}=19,44 \mathrm{~mm} / 1000 \mathrm{daN}
$$

Podatność maksymalna sprężyny zewnętrznej w ujęciu statystycznym wynosi odpowiednio:

$$
\mathrm{c}_{\text {OSTATMIN }}=20,92 \mathrm{~mm} / 1000 \mathrm{daN}
$$

Przedstawiając zależności (48), (49) oraz (51) w formie odchyłek od wartości nominalnej otrzymuje się zależność:

$$
\mathrm{c}_{\text {OSTAT }}=20,07_{-0,49}^{+0,61} \mathrm{~mm} / 1000 \mathrm{daN}
$$
zależność:

Wyrażając odchyłki podatności w formie procentowej od wartości nominalnej otrzymuje się

$$
\mathrm{c}_{\text {OSTAT }}=20,07_{-2,44 \%}^{+3,03 \%} \mathrm{~mm} / 1000 \mathrm{daN}
$$

Jak widać z przeprowadzonej analizy, w przypadku założenia, że odchyłki mające wpływ na podatność (sztywność) pręta mają rozkład losowy zgodny z rozkładem normalnym to wówczas warunek tolerancji podatności, założonej w zakresie $\pm 8 \%$ wartości nominalnej jest spełniony z dużą rezerwą. 


\section{Konstrukcja sprężyny, a przyjmowana energia sprężysta}

W niniejszym artykule oraz w opracowaniach [3 i 4] wykazano, że obydwie sprężyny wewnętrzna oraz zewnętrzna wózka Y25L są mocno wytężone. Wytężenie materiału sprężyny można poszczególnych sprężyn można porównać przez wykonanie rachunku energetycznego. W przypadku sprężyny zewnętrznej maksymalna energia sprężysta pochłonięta przez sprężynę zewnętrzną wynosi:

$$
\mathrm{E}_{\mathrm{MAX} 1}=\frac{1}{2} \cdot \mathrm{k}_{1} \cdot \mathrm{f}_{1 \mathrm{MAX}}^{2}
$$

Wstawiając dane liczbowe do wzoru (84) tzn. $\mathrm{k}_{1}=49,82 \mathrm{daN} / \mathrm{mm}$ oraz $\mathrm{f}_{1 \mathrm{MAX}}=18+60 \mathrm{~mm}=0,78 \mathrm{~m}$ otrzymuje się:

$$
\mathrm{E}_{\mathrm{MAX} 1}=\frac{1}{2} \cdot 49,82 \cdot 10^{4} \cdot 0,78^{2} \cdot 10^{-3}=151,55 \mathrm{~kJ}
$$

Dla porównania, sprężyna wewnętrzna przejmuje energię sprężystą, określoną wzorem:

$$
\mathrm{E}_{\mathrm{MAX} 2}=\frac{1}{2} \cdot \mathrm{k}_{2} \cdot \mathrm{f}_{2 \mathrm{MAX}}^{2}
$$

Wstawiając dane liczbowe do wzoru (84) tzn. $\mathrm{k}_{2}=82,17 \mathrm{daN} / \mathrm{mm}$ oraz $\mathrm{f}_{2 \mathrm{MAX}}=52 \mathrm{~mm}=0,52 \mathrm{~m}$ otrzymuje się:

$$
\mathrm{E}_{\mathrm{MAX} 2}=\frac{1}{2} \cdot 82,17 \cdot 10^{4} \cdot 0,52^{2}=111,09 \mathrm{~kJ}
$$

Energia sprężysta przejęta przez sprężynę zewnętrzną oraz wewnętrzną wózka Y25L w stanie próżnym wagonu towarowego o masie $20000 \mathrm{~kg}$ :

$$
\mathrm{E}_{1}=\frac{1}{2} \cdot \mathrm{k}_{1} \cdot \mathrm{f}_{\mathrm{ZPR}}^{2}
$$

Po wstawieniu danych liczbowych do wzoru (88) tzn. $\mathrm{k}_{1}=49,82 \mathrm{daN} / \mathrm{mm}=49,82 \cdot 10^{4} \mathrm{~N} / \mathrm{m}$ oraz $\mathrm{f}_{\mathrm{ZPR}}$ ? $18 \mathrm{~mm}=0,18 \mathrm{~mm}$ otrzymuje się:

$$
\mathrm{E}_{1}=\frac{1}{2} \cdot 49,82 \cdot 10^{4} \cdot 0,18^{2} \cdot 10^{-3}=8,07 \mathrm{~kJ}
$$

Energia sprężysta przejęta przez sprężynę wewnętrzną w stanie próżnym wagonu $\mathrm{E}_{2}=0$.

Energia sprężysta przejęta przez sprężynę zewnętrzną w stanie ładownym wagonu o masie brutto $90000 \mathrm{~kg}$ wynosi:

$$
\mathrm{E}_{1 \mathrm{LAD}}=\frac{1}{2} \cdot \mathrm{k}_{1} \cdot\left(\mathrm{f}_{\mathrm{ZPR}}+\Delta \mathrm{f}+\mathrm{f}_{2}\right)
$$

Po wstawieniu danych liczbowych do wzoru (90) tzn. $\mathrm{k}_{1}=49,82 \mathrm{daN} / \mathrm{mm}=49,82 \cdot 10^{4} \mathrm{~N} / \mathrm{m}$ oraz $\mathrm{f}_{\mathrm{ZPR}}+\Delta \mathrm{f}+\mathrm{f}_{2}=18+8+29,50=55,5 \mathrm{~mm}=0,55 \mathrm{~m}$ :

$$
\mathrm{E}_{1 \mathrm{LAD}}=\frac{1}{2} \cdot 49,82 \cdot 10^{4} \cdot 0,555^{2} \cdot 10^{-3}=76,72 \mathrm{~kJ}
$$

Energia sprężysta przejęta przez sprężynę wewnętrzną $\mathrm{w}$ stanie ładownym wagonu o masie brutto $90000 \mathrm{~kg}$ wynosi:

$$
\mathrm{E}_{2 \mathrm{LAD}}=\frac{1}{2} \cdot \mathrm{k}_{2} \cdot \mathrm{f}_{2}^{2}
$$

Po wstawieniu danych liczbowych do wzoru (92) tzn. $\mathrm{k}_{2}=82,17 \mathrm{daN} / \mathrm{mm}=82,17 \cdot 10^{4} \mathrm{~N} / \mathrm{m}$ oraz $\mathrm{f}_{2}=29,50 \mathrm{~mm}=0,295 \mathrm{~m}$ wynosi:

$$
\mathrm{E}_{2 \mathrm{LAD}}=\frac{1}{2} \cdot 82,17 \cdot 10^{4} \cdot(0,295)^{2} \cdot 10^{-3}=35,75 \mathrm{~kJ}
$$

Porównanie energii sprężystych przejętych przez sprężyny zewnętrzne oraz wewnętrzne wózka Y25L w poszczególnych stanach załadowania wagonu jest przedstawione na rys.8.

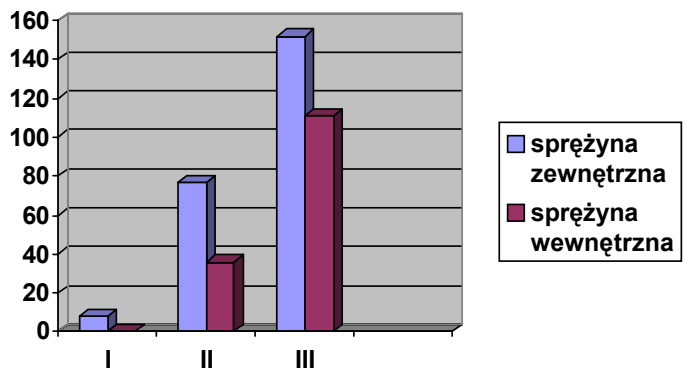

Legenda:

Oś pozioma X: I - stan próżny wagonu, II - stan ładowny, III stan maksymalny

Oś pionowa $Y$ : kJ

Rys.8. Porównanie energii sprężystych przejętych przez sprężynę zewnętrzną oraz sprężynę wewnętrzną w różnych stanach załadowania wagonu

\section{WNIOSKI}

Z przeprowadzonych analiz wynika, że w celu zapewnienia właściwej wytrzymałości statycznej oraz zmęczeniowej konieczne jest podjęcie przez producenta właściwego reżimu technologicznego i procesów odbiorczych w celu zapewnienia odpowiedniej jakości. Sprężyny wózka Y25L nie są jedynymi elementami, posiadającymi kompaktową budowę i przenoszacymi poważne siły statyczne oraz dynamiczne. W wielu pojazdach konstruowanych obecnie miejsce wyznaczone dla układu biegowego jest ograniczone, co sprawia że elementy są bardzo poważnie wytężone podczas eksploatacji. Zmusza to konstruktorów do poszukiwania dalszych, bardziej wydajnych rozwiązań pod względem funkcjonalnym oraz wytrzymałościowym, zapewniających oprócz kompaktowej (zwartej) budowy, wysoką wytrzymałość oraz trwałość. Aby zapewnić wymaganą żywotność sprężyn zawieszenia pierwotnego, konieczne jest prawidłowe funkcjonowanie thumika ciernego, co wymaga między innymi zastosowania płytek odpornych na ścieranie wg karty UIC 893 [11]. Kompaktowa budowa wózka jest powiązana $\mathrm{z}$ wymogiem minimalnej masy własnej układu biegowego, a tym samym wagonu towarowego. W takim przypadku można zrealizować możliwie maksymalną ładowność wagonu towarowego, co przyczynia się do wzrostu konkurencyjności transportu kolejowego ładunków, w stosunku do pozostałych rodzajów transportu, zwłaszcza drogowego. Aby sprężyny 
wózka dwuosiowego wagonu towarowego Y25L spełniły wszechstronne wymagania, konieczne jest opracowanie właściwej dokumentacji wykonawczej przez konstruktora, zastosowanie prawidłowej technologii wykonania i odbiorów oraz zapewnienie prawidłowej eksploatacji, przez utrzymanie zawieszenia przymaźnicznego w prawidłowym stanie, opartym o wytyczne zawarte w DSU.

\section{LITERATURA}

[1] Kaiser B.: Untersuchung des Korrosionsschutzes an Schraubenfedern für Schienenfahrzeuge. Eisenabahntechnische Rundschau Nr. 7+8/2008.

[2] Schmidt D.: Tragfeder aus Stahl für Schienenfahrzeuge. Konstruktion, Berechnung, Fertigung. Eine Veröffentlichung des Federnwerkes Langen \& Sondermann GmbH\&Co.KG. 2002.

[3] Sobaś M: Problematyka usprężynowania wózków wagonów towarowych typu Y25. Pojazdy Szynowe nr 1/2014.

[4] Sobaś M.: Analiza uspreżynowania wózków wagonów towarowych typu Y25. Pojazdy Szynowe nr 2/2014.

[5] Karta UIC 432: Wagony towarowe. Prędkości jazdy. Warunki techniczne, które należy spetnić. 11-te wydanie 09/2006.

[6] Karta UIC 500: Normalizacja taboru transportowego $i$ jego elementów. Zasady, procedury, 2-gie wydanie, grudzień 2000.

[7] Karta UIC 510-1: Wagony towarowe. Uktad biegowy standaryzacja. 9-te wydanie z 1.01.78. 14-ście zmian od 1.01.80 do 1.01.97.

[8] Karta UIC 517: Wagony towarowe. Części zawieszenia resorowego. Normalizacja. 7dme wydanie z maja 2007.

[9] Karta UIC 518: Badania i homologacja pojazdów kolejowych z punktu widzenia wtaściwości dynamicznych, bezpieczeństwa jazdy, obciqżenia toru i parametrów biegowych. 4-te wydanie z października 2009.
[10] Karta UIC 822: Warunki techniczne dostawy sprężyn śrubowych naciskowych formowanych na goraco lub na zimno dla pojazdów trakcyjnych $i$ wagonów. 5-te wydanie z 11.2003

[11] Karta UIC 893: Warunki techniczne dla dostawy blach na plyty prowadnicowe ze stali manganowej. 2gie wydanie. 06.2004.

[12] PN-EN 10089:2002 Stale walcowane na goraco na sprężyny ulepszane cieplnie. Warunki techniczne dostawy.

[13] PN-EN 13298:2003: Kolejnictwo. Elementy zawieszenia. Stalowe sprę̇yny śrubowe zawieszenia.

[14] PN-EN 14363:2007 Kolejnictwo. Badania wtasności dynamicznych przed dopuszczeniem pojazdów szynowych. Badanie wtaściwości biegowych i próby stacjonarne.

[15] Raport ORE/ERRI: Frage B12 Vereinheitlichung der Güterwagen. Standard-Drehgestell. Bericht Nr.14.Utrecht, 11.1967.

[16] Schlussbericht ERRI B12/Rp.17 (8-me wydanie): Program badań wagonów towarowych z podwoziem $i$ strukturq wagonu ze stali (które nadaja sie do zabudowy sprzęu pracujacego na ściskanie) $i$ których wózki maja rame stalowa. (Versuchsprogramm für Güterwagen mit Untergestell und Wagenkasten aus Stahl (die für den Einbau der Automatischen Zug-Druck Kupplung geeignet sind) und deren Drehgestelle mit stählernem Drehgestellrahmen). Utrecht, 04.1997.

[17] Raport ORE/ERRI B55: Sicherheit gegen Entgleisen von Güterwagen in Gleisverwindungen. Bericht 8 (Schlussbericht). Utrecht, April 1983.

[18] TSI: Dziennik Urzędowy Unii Europejskiej. Decyzja Komisji z dnia 13 marca 2013 dotyczqca technicznej specyfikacji dla interoperacyjności odnoszacej się do podsystemu "tabor kolejowy - wagony towarowe" transeuropejskiego systemu kolei konwencjonalnych.

[19] Norma DIN 2089 Teil 1: Zylindrische Schraubenfedern aus runden Drähten und Stäben. Berechnung und Konstruktion. 